\title{
FEATURES OF THE PARASITIC SYSTEM FORMATION IN COMMON CARP IN THE AQUACULTURE OF THE NORTH-EASTERN AND EASTERN REGIONS OF UKRAINE
}

\author{
Yevtushenko A. V. \\ National Scientific Center 'Institute of Experimental and Clinical Veterinary \\ Medicine', Kharkiv, Ukraine, e-mail: aevt76@gmail.com
}

\begin{abstract}
Summary. The research aimed to determine the peculiarities of the formation of the parasitic system in common carp in the aquaculture of the North-Eastern and Eastern regions of Ukraine. According to the results of the research, 27 species of parasites were found in common carp (12 - protozoa, 6 - monogeneans, 3 - trematodes, 2 - cestodes, 4 - parasitic crustaceans). Three species (11.1\%) of registered parasites were invasive. 22 species $(81.5 \%)$ of detected common carp's parasites develop directly and $5(18.5 \%)$ - with the participation of definitive and intermediate hosts. 26 species (96.3\%) of common carp's parasitic fauna were found in crucian carp and 21 species (77.8\%) in other coarse fish species (roach, rudd, bleak, perch). It has been established that among the protozoa, pathogens from the genera Trichodina, Chilodonella, and Ichthyophthirius were of epizootic importance for young common carp; Eimeria carpelli, Ichthyobodo necator, Myxobolus ellipsoides, and Myxobolus dogieli had relevance. The level of prevalence in common carp fingerlings during outbreaks of chylodonelosis was $72 \%$, two-year-olds $-65 \%$, three-year-olds $-27 \%$, during outbreaks of ichthyoftiriosis - 45\%,56\%, and 24\%, respectively. Prevalence of Trichodina acuta and Trichodina nigra in common carp fingerlings was, respectively, $52 \%$ and $38 \%$, Ichthyobodo necator - 16\%, Eimeria carpelli- 22\%, Myxobolus ellipsoides, and Myxobolus dogieli- 17-18\%. Among the pathogens of helminthic diseases in the aquaculture, monogenetic suckers (Dactylogyrus anchoratus, Dactylogyrus extensus, Dactylogyrus vastator, Gyrodactylus cyprini, and Gyrodactylus katharineri), as well as cestodes (Bothriocephalus acheilognathi and Khawia sinensis) were the most epizootic significance for common carp. Prevalence of parasites from the genus Dactylogyrus reached $68-87 \%$ in fingerlings, from the genus Gyrodactylus - 21-36\%. The highest level of Bothriocephalus acheilognathi infection (82\%) was registered in fingerlings. The maximum prevalence of Khawia sinensis (62\%) was observed in two-year-olds. Outbreaks of diseases caused by crustaceans Lernaea cyprinacea and Argulus foliaceus with a high level of prevalence have been reported in fish from fingerlings to three-year-olds. The level of prevalence of Lernaea cyprinacea was 69\%, Argulus foliaceus - 22\%
\end{abstract}

Keywords: parasitic system, protozoa, helmints, parasitic crustaceans, common carp, aquaculture

Introduction. The most common object of freshwater aquaculture in Ukraine is the common carp (Cyprinus carpio Linnaeus, 1758). It was bred by domestication of wild carp. This species of fish is resistant to adverse factors of the aquatic environment - does not die from the reduction of dissolved oxygen in water to $0.8-1.0 \mathrm{mg} / \mathrm{dm}^{3}$, can withstand high densities of placing, transportation. Common carp is quite resistant to a number of parasitic and infectious diseases. The temperature optimum for reproduction, nutrition and growth is $18-26^{\circ} \mathrm{C}$. In the conditions of fish farms of Ukraine, common carp is grown mainly in the polyculture together with herbivorous species, which allows to make maximum use of the natural fodder base of reservoirs, because under such farming conditions fish species are not food competitors (Hrynzhevskyi, 1998; Andriushchenko and Alymov, 2008). However, high placing density with intensification of farming methods, hydrological links of ponds, the presence of aboriginal fish species, a large number of piscivorous birds provoke outbreaks of parasitic diseases and, as a consequence, reduced fish productivity. It should be noted that coarse fish species (crucian carp, roach, rudd, bleak, perch, etc.) are of great importance in the formation of the center of invasions. These fish species are often reservoir of invasions and can be a source of infection and a cause of disease outbreaks (Davydov and Temnikhanov, 2003). There are many scientific works devoted to the study of parasitocenoses of industrial fish species in inland waters of Ukraine. However, the parasitic fauna of common carp differs in different regions. In addition, seasonal and age dynamics of infection of fish has its own characteristics (Davydov et al., 2005, 2011; Pukalo and Loboiko, 2005; Sachuk and Yuskiv, 2010; Katiukha and Vozniuk, 2016; Mandyhra and Zbozhynska, 2008). Separate studies have focused on the role of non-industrial ichthyofauna in the spread of pathogens (Katyukha and Orel, 2018).

The purpose of the study was to determine the peculiarities of the formation of the parasitic system in common carp in the aquaculture of the North-Eastern and Eastern regions of Ukraine. In this regard, the following tasks were set: to study the species composition of parasites, to determine the level of infection of fish, to study the age dynamics of infection, to identify epizootically significant species of parasites that can cause disease outbreaks. 
Materials and methods. Fifteen specimens of each fish species and age groups were studied in a specialized laboratory of the National Scientific Center 'Institute of Experimental and Clinical Veterinary Medicine' (Kharkiv, Ukraine). Ichthyological material was taken in different seasons of the year from spawning, growing, feeding, and wintering ponds in specialized fish farms, as well as agricultural ponds of Kharkiv, Sumy, Poltava, and Donetsk regions.

Ichthyological analysis was performed by the method of incomplete helminthological autopsy according to Bykhovskaya-Pavlovskaya (1985) and Markevich (1951). Species affiliation of parasites was determined by the 'Keys to Parasites of Freshwater Fish of the Fauna of the USSR' (Bauer, 1984, 1985, 1987).
Prevalence of infection (PI, \%) was determined by the formula:

$$
P I=\frac{x}{y} \times 100 \%
$$

where: $\mathrm{x}-$ the number of fish in which parasites were found; $y$ - the total number of studied fish.

Statistical processing of the obtained results was carried out following the recommendations on biometrics using the parametric Student's $t$-test (Van Emden, 2019).

Results and discussion. According to the results of the research (Table 1), 27 species of parasites were found in common carp: 12 species (44.4\%) of protozoa, $6(22.2 \%)$ - monogeneans, 3(11.1\%) - trematodes, $2(7.4 \%)$ - cestodes, $4(14.8 \%)$ - parasitic crustaceans.

Table 1 - Species composition of common carp's, crucian carp's, and coarse fish's parasites and places of their localization in the conditions of aquaculture of the North-Eastern and Eastern regions of Ukraine

\begin{tabular}{|c|c|c|c|c|c|}
\hline \multirow[b]{2}{*}{ No. } & \multirow[b]{2}{*}{ Parasite species } & \multirow[b]{2}{*}{ Localization } & \multicolumn{3}{|c|}{ Fish species } \\
\hline & & & $\begin{array}{l}\text { Com- } \\
\text { mon } \\
\text { carp }\end{array}$ & $\begin{array}{l}\text { Cru- } \\
\text { cian } \\
\text { carp }\end{array}$ & $\begin{array}{l}\text { Other coarse fish } \\
\text { (roach, rudd, } \\
\text { bleak, perch) }\end{array}$ \\
\hline 1 & ${ }^{*}$ Cryptobia branchialis (Nie in Chen, 1956) & gills & + & + & ++ \\
\hline 2 & Ichthyobodo necator (= Costia necatrix) (Henneguy, 1883) & gills, skin & + & + & + \\
\hline 3 & Eimeria carpelli Leger et Stankovitch, 1921 & intestine & + & + & + \\
\hline 4 & Myxobolus cyprini Doflein, 1898 & kidneys, muscles & + & + & + \\
\hline 5 & Myxobolus carassii Klokačeva, 1914 & gills, abdomen & + & + & + \\
\hline 6 & Myxobolus ellipsoides Thélohan, 1892 & all organs and tissues & + & + & + \\
\hline 7 & $\begin{array}{r}\text { Myxobolus dogieli Bykhovskaya-Pavlovskaya } \\
\text { et Bykhovski, } 1940\end{array}$ & $\begin{array}{l}\text { kidneys, intestine } \\
\text { wall, gills }\end{array}$ & + & - & - \\
\hline 8 & Chilodonella piscicola (Zacharias, 1894) Jankowski, 1980 & gills, body surface & + & + & + \\
\hline 9 & Ichthyophthirius multifiliis Fouquet, 1876 & gills, body surface & + & + & + \\
\hline 10 & Trichodina acuta Lom, 1961 & gills, body surface & + & + & + \\
\hline 11 & Trichodina nigra Lom, 1961 & gills, body surface & + & + & + \\
\hline 12 & $\begin{array}{r}\text { Trichodinella epizootica (Raabe, 1950) } \\
\text { Sramek-Husek, } 1953\end{array}$ & gills, body surface & + & + & + \\
\hline 13 & Dactylogyrus anchoratus (Dujardin, 1845) & gills & + & + & - \\
\hline 14 & Dactylogyrus vastator Nybelin, 1924 & gills & + & + & - \\
\hline 15 & Dactylogyrus extensus Mueller et Van Cleave, 1932 & gills & + & + & - \\
\hline 16 & Gyrodactylus cyprini Diarova, 1964 & gills, body surface & + & + & - \\
\hline 17 & Gyrodactylus katharineri Malmberg, 1964 & gills, body surface & + & + & + \\
\hline 18 & Diplozoon paradoxum von Nordmann, 1832 & gills & + & + & + \\
\hline 19 & Diplostomum spathaceum (Rudolphi, 1819) mtc & eyes & + & + & + \\
\hline 20 & Posthodiplostomum cuticola (Nordmann, 1832) mtc & skin & + & + & + \\
\hline 21 & $\begin{array}{r}\text { Ichthyocotylurus variegatus (= Tetracotyle variegate) } \\
\text { (Creplin, 1825) Odening, } 1969 \mathrm{mtc}\end{array}$ & abdomen & + & + & + \\
\hline 22 & ${ }^{\star}$ Khawia sinensis Hsü, 1935 & intestine & + & + & + \\
\hline 23 & ${ }^{*}$ Bothriocephalus acheilognathi Yamaguti, 1934 & intestine & + & + & + \\
\hline 24 & Philometra sanguinea (Rudolphi, 1819) & fins & - & + & - \\
\hline 25 & Ergasilus sieboldi von Nordmann, 1832 & gills & + & + & - \\
\hline 26 & Ergasilus briani Markevich, 1933 & gills & + & + & + \\
\hline 27 & Lernaea cyprinacea Linnaeus, 1758 & skin & + & + & + \\
\hline 28 & Argulus foliaceus (Linnaeus, 1758) & skin & + & + & + \\
\hline
\end{tabular}

Remarks: ${ }^{*}$ - invasive species, mtc - metacercariae. 
Only 3 species (11.1\%) from the detected parasites are invasive species. It should be noted that 22 species (81.5\%) of detected common carp's parasites develop directly and $5(18.5 \%)$ - with the participation of definitive and intermediate hosts. Herewith, the fish is an additional (second intermediate) host in the life cycle of 3 species (11.1\%) of parasites.

In common carp 18 species (66.7\%) of the detected pathogens are parasites of the surface of the body, skin and gills, three species are parasites of the intestine, one species - a parasite of the eyes, one species - a parasite of the abdominal cavity. Representatives of the genus Myxobolus were found in various organs and tissues.

It was found that only one species from the genus Myxobolus showed specificity to the host: $M$. dogieli was found only in common carp. Representatives of the genus Dactylogyrus were found only in common carp and crucian carp. G. katharineri was found in all studied carp fish, while G. cyprini - only in common carp and crucian carp. It should be noted that nematodes of the genus Philometra were not detected in common carp, but a species-specific parasite Ph. sanguinea was detected in crucian carp.

Thus, according to the obtained data, it was established that $96.3 \%$ of common carp's parasitic fauna were found in crucian carp and $77.8 \%$ - in other coarse fish species (roach, rudd, bleak, perch). This fact must be taken into account when planning preventive and anti-epizootic measures in the fight against parasitic diseases of common carp in aquaculture.

According to the results of studying the age dynamics of common carp infection with pathogens of protozoa infectious diseases, the data shown in Fig. 1 were obtained.

Thus, the data in Fig. 1 show that outbreaks of diseases caused by parasitic protozoa were recorded mainly fingerlings and two-year-olds. Flagellates C. branchialis were found in $8-10 \%$ of fingerlings and two-year-olds, and I. necator mainly in fingerlings (16\%), less often in twoyear-olds (7\%).

Sporozoa M. cyprini and M. carassii with almost the same prevalence of infection (7-10\%) were registered in fish of both fingerlings and two-year-olds, while M. ellipsoides and M. dogieli were registered mainly in fingerlings (17-18\%).

Outbreaks of eimeriosis (E. carpelli) were observed in $22 \%$ of common carp fingerlings, and only parasite carriage was recorded in older fish.

It should be noted that among all detected protozoa outbreaks of the diseases among three-year-old fish were registered when infection by pathogens Ch. piscicola and I. multifiliis. High levels of infection were observed both among fingerlings $-72 \%$ and $45 \%$, among two-yearolds $-65 \%$ and $56 \%$, and among three-year-olds $-27 \%$ and $24 \%$, respectively.

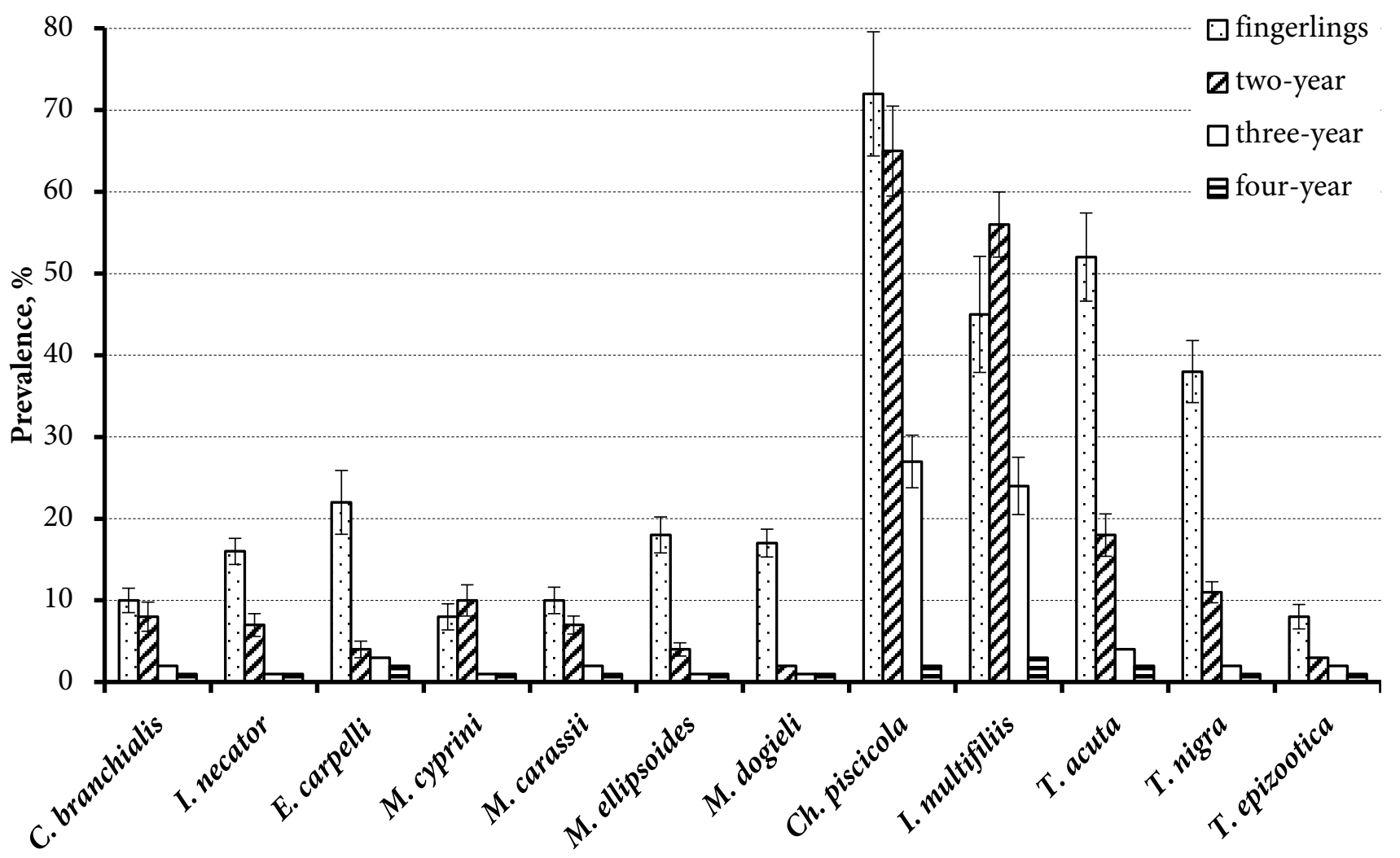

Figure 1. Age dynamics of infection of common carp with pathogens of protozooses during outbreaks of diseases in fish farms of the North-Eastern and Eastern regions of Ukraine 
A different picture was observed when infecting fish with pathogens of other ciliaphorosis - T. acuta, T. nigra, T. epizootica: the highest level of infection was registered in fingerlings $-52 \%, 38 \%, 8 \%$, and the infection of twoyear-olds was much lower $-18 \%, 11 \%, 3 \%$, respectively. Infection of four-year-olds with protozoa was practically not registered, and the level of mean intensity testified to parasitic carriers of pathogens.

When studying the seasonal dynamics of fish infection with protozoa, it was found that infection of fingerlings and two-year-old common carp with myxosporidia (M. cyprini, M. carassii, M. ellipsoides, M. dogieli) was recorded throughout the summer and the maximum level of prevalence was recorded in autumn. In winter, the level of infection decreased. A similar pattern was observed when infecting fish with the causative agent of eimeriosis - E. carpelli.

Among fingerlings, the peak level of infection with parasites I. necator was recorded in July. An increase in the infection of fish with T. nigra and T. epizootica was observed in August. In August-September, the maximum infection of fingerlings and two-year-olds with C. branchialis was determined.

Outbreaks of ichthyoftiriosis infection (I. multifiliis) were more often registered in spawning ponds when growing young, as well as in the autumn among common carp of different age groups after transferring to winter ponds. The highest level of infection of fish with
C. piscicola and T. acuta was recorded in winter ponds from October to April.

Thus, according to the results of the conducted researches it was established that the pathogens from the genera Trichodina, Chilodonella, and Ichthyophthirius had the greatest epizootic significance for the young common carp; representatives of the genera Eimeria and Ichthyobodo, as well as some species from the genus Myxobolus were relevant. Fish of older age groups were parasitic carriers of protozoa, only species C. piscicola and I. multifiliis sometimes caused outbreaks of diseases under the high density of placing - in winter ponds.

The age dynamics of common carp infection with helminthiasis and crustaceosis pathogens during disease outbreaks in fish farms in the North-Eastern and Eastern regions of Ukraine is shown in Fig. 2.

The data in Fig. 2 show that outbreaks of dactylogyrosis and gyrodactylosis were recorded primarily in fingerlings, with prevalence by parasites of the genus Dactylogyrus reaching $68-87 \%$, while prevalence by parasites of the genus Gyrodactylus in fingerlings - 21$36 \%$. Older fish were parasitic carriers of pathogens. D.paradoxum monogeneans had no epizootic significance - they were recorded only sporadically.

Metacercariae of trematodes P.cuticola, D. spathaceum, I. variegatum were registered both in fingerlings and two-year-olds, but the level of prevalence ranged from $8-13 \%$.

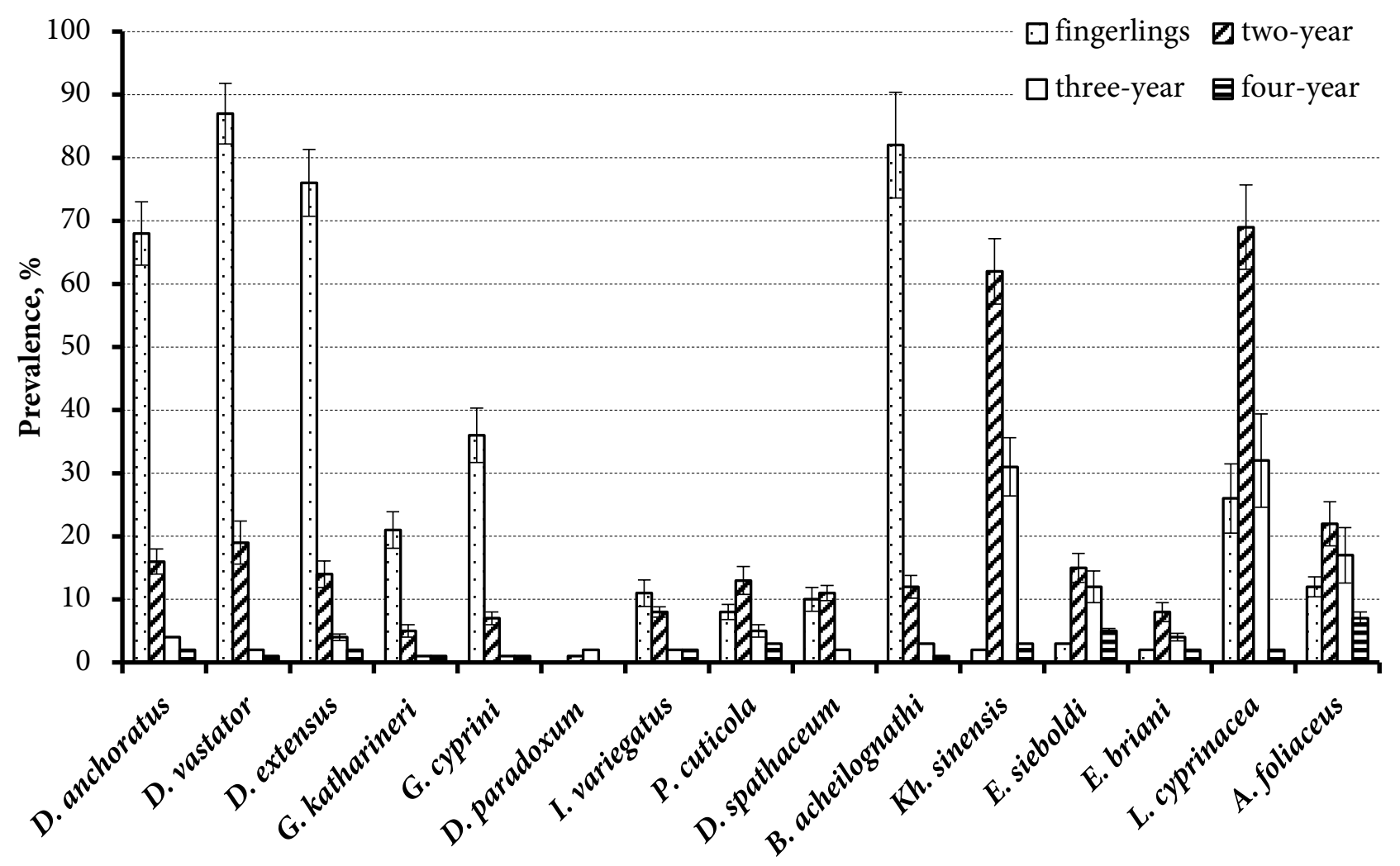

Figure 2. Age dynamics of infection of common carp with helminthic and crustacean pathogens in disease outbreaks in fish farms in the North-Eastern and Eastern regions of Ukraine 
The opposite pattern was observed when common carp was infected with cestodes B.acheilognathi and Kh. sinensis. Thus, the highest level of infection with B. acheilognathi was registered in fingerlings $-82 \%$, with an infection of two-year-olds no more than $12 \%$.

Instead, the maximum prevalence with Kh. sinensis was registered in two-year-olds - 62\%, while among these-year-olds the level of infection did not exceed 2\%. A high level of infection with $K h$. sinensis was registered in three-year-old fish $-31 \%$. These cestodes have a complex cycle of development: for B. acheilognathi intermediate hosts are cyclops, and for Kh. sinensis - oligochaetes. Common carp in the first months of life has a planktonic type of food, and later - benthic, which explains the difference in the age dynamics of infection.

According to the obtained data, parasitic crustaceans were more often found in two-year-old fish. Thus, the highest level of prevalence of two-year-old common carp L. cyprinacea was $69 \%$, E. sieboldi - 15\%, E. briani - 8\%, A. foliaceus $-22 \%$, and fingerlings $-26 \%, 3 \%, 2 \%, 12 \%$, respectively. High levels of L. cyprinacea and A. foliaceus infection were reported in unfavorable farms and among three-year-old fish $-32 \%$ and $17 \%$, respectively.

The results of the analysis of the seasonal dynamics of fish infection with pathogens of monogenoidosis showed some of its features during the year. Thus, the outbreak of infection of D. anchoratus, D. extensus were registered among fingerlings in June, in July the level of infection decreased slightly, but in August there was a sharp increase in prevalence to $68 \%$ and $76 \%$, respectively. Another picture was observed with $D$. vastator infection: in June, the peak of infection was registered - up to $87 \%$, then the prevalence decreased, but it increased again in September, but not more than $40 \%$. As the water temperature decreased, the prevalence decreased. Pathogens G. cyprini and G. katharineri, on the contrary, were found mainly in fingerlings in the spring in winter ponds.

Infection with pathogens of trematode infections (P. cuticola, D. spathaceum, I. variegatus) was recorded throughout the growing season. The peak of infection was observed in the autumn. During the winter, the level of P. cuticola infection decreased, while the prevalence of D. spathaceum and I. variegatus did not change.

During the whole summer period, common carp infection with B.acheilognathi cestodes was also registered, and the prevalence gradually increased and gained maximum value in August-September. Another picture was observed during infection with cestodes Kh. sinensis: the first peak of the infection was observed in fingerlings in the spring, and after re-infection during the spring-summer period, the second peak of the infection was recorded - in two-year-olds, in the autumn.

The highest level of infection with parasitic crustaceans from the genera Ergasilus and Lernaea was recorded throughout the summer period with the maximum level of prevalence in July-August. Crustaceans A.foliaceus were recorded on fish throughout the year, but the peak of infection was observed in June-July.

Thus, the results of the study showed that monogenetic suckers (D. anchoratus, D. extensus, D. vastator, G. cyprini, G. katharineri), cestodes (B. acheilognathi, Kh. sinensis), crustaceans (L.cyprinacea and A.foliaceus) had the greatest epizootic value in aquaculture for common carp.

Our results on the epizootic significance of the detected pathogens are confirmed by the data of other authors. Significant species diversity of freshwater fish parasites in natural hydroecosystems is considered harmless. However, under the conditions of artificial cultivation, many species of pathogens can cause epizooty, lead to pathologies in the body of fish, lead to a decrease in fish productivity.

First of all, such pathogens include protozoa, monogeneans and parasitic crustaceans (Mikheev, Pasternak and Valtonen, 2003; Wei, Li and Yu, 2013; Bastos Gomes et al., 2017; Molnár, 1996; Molnár and Székely, 2014; Lux, 1990). Invasive parasites play a significant role in the epizootology of parasitic diseases (Scholz, Kuchta and Williams, 2012; Oros, Hanzelová and Scholz, 2009). The increase in the number of piscivorous birds associated with environmental measures is contributing to the increase in the infection of common carp and other pond fish with trematode metacercariae.

Data on the epizootic significance of trematode infections are confirmed by other researchers (Ondracková et al., 2004; Jithila and Prasadan, 2018; Georgieva et al., 2013). The obtained results on the infection of non-industrial fish species with pathogens of parasitic diseases dangerous to common carp, are consistent with the data of O. M. Davydov (Davydov and Temnikhanov, 2003; Davydov etal., 2011, 2012), according to which coarse fish can be a reservoir of a number of dangerous parasitic diseases such as ichthyoftiriosis, chylodonellosis, lerneosis, etc.

Conclusions. 1. In fish farms of the North-Eastern and Eastern regions of Ukraine, 27 species of parasites were found in common carp: 12 - protozoa, 6 - monogeneans, 3 - trematodes, 2 - cestodes, $4-$ parasitic crustaceans. Three species (11.1\%) of registered parasites were invasive. 22 species $(81.5 \%)$ of detected common carp's parasites develop directly and $5(18.5 \%)$ - with the participation of definitive and intermediate hosts. 26 species (96.3\%) of common carp's parasitic fauna were found in crucian carp and 21 species (77.8\%) in other coarse fish species (roach, rudd, bleak, perch).

2. It has been established that among the protozoa, pathogens from the genera Trichodina, Chilodonella, and Ichthyophthirius were of epizootic importance for young common carp; Eimeria carpelli, Ichthyobodo necator, Myxobolus ellipsoides, and Myxobolus dogieli had relevance. The level of prevalence in common carp 
fingerlings during outbreaks of chylodonelosis was $72 \%$, two-year-olds - $65 \%$, three-year-olds - $27 \%$, during outbreaks of ichthyoftiriosis - $45 \%, 56 \%$, and $24 \%$, respectively. Prevalence of Trichodina acuta and Trichodina nigra in common carp fingerlings was, respectively, $52 \%$ and $38 \%$, Ichthyobodo necator - 16\%, Eimeria carpelli- 22\%, Myxobolus ellipsoides, and Myxobolus dogieli - 17-18\%.

3. Among the pathogens of helminthic diseases in the aquaculture, monogenetic suckers (Dactylogyrus anchoratus, Dactylogyrus extensus, Dactylogyrus vastator, Gyrodactylus cyprini, and Gyrodactylus katharineri), as well as cestodes (Bothriocephalus acheilognathi and Khawia sinensis) were the most epizootic significance for common carp. Prevalence of parasites from the genus Dactylogyrus reached $68-87 \%$ in fingerlings, from the genus Gyrodactylus - 21-36\%. The highest level of Bothriocephalus acheilognathi infection (82\%) was registered in fingerlings. The maximum prevalence of Khawia sinensis (62\%) was observed in two-year-olds.
4. Outbreaks of diseases caused by crustaceans Lernaea cyprinacea and Argulus foliaceus with a high level of prevalence have been reported in fish from fingerlings to three-year-olds. The level of prevalence of Lernaea cyprinacea was $69 \%$, Argulus foliaceus $-22 \%$.

Prospects for further research. The obtained results on the age and seasonal dynamics of infection allow the introduction of a set of treatment and prevention measures in the control of pathogens (Dunn and Hatcher, 2015). Thus, to combat monogenetic suckers and parasitic crustaceans, it is recommended to take preventive measures at the beginning of the growing season - in June among fish of all ages.

Therapeutic treatment of fish with larval trematodes is recommended twice - in July and in September among fingerlings and two-year-olds. The most effective period for intestinal cestodes treatment is August-September. Preventive treatment of fish of all ages with parasitic protozoa should be carried out after transferring fish to winter ponds.

\section{References}

Andriushchenko, A. I. and Alymov S. I. (2008) Pond Fish Farming [Stavove rybnytstvo]. Kyiv: National Agrarian University Publish Center. ISBN 9789668689031. [in Ukrainian].

Bastos Gomes, G., Miller, T. L., Vaughan, D. B., Jerry, D. R., McCowan, C., Bradley, T. L. and Hutson, K. S. (2017) 'Evidence of multiple species of Chilodonella (Protozoa, Ciliophora) infecting Australian farmed freshwater fishes', Veterinary Parasitology, 237, pp. 8-16. doi: 10.1016/j.vetpar.2017.03.004.

Bauer, O. N. (ed.) (1984) Keys to Parasites of Freshwater Fish of the Fauna of the USSR. Volume 1. Parasitic Protozoa [Opredelitel' parazitov presnovodnykh ryb fauny SSSR. Tom 1. Paraziticheskie prosteyshie] (3 vols). Leningrad: Nauka. [in Russian].

Bauer, O. N. (ed.) (1985) Keys to Parasites of Freshwater Fish of the Fauna of the USSR. Volume 2. Parasitic Metazoa (Chapter 1) [Opredelitel' parazitov presnovodnykh ryb fauny SSSR. Tom 2. Paraziticheskie mnogokletochnye (Pervaya chast')] (3 vols). Leningrad: Nauka. [in Russian].

Bauer, O. N. (ed.) (1987) Keys to Parasites of Freshwater Fish of the Fauna of the USSR. Volume 3. Parasitic Metazoa (Chapter 2) [Opredelitel' parazitov presnovodnykh ryb fauny SSSR. Tom 3. Paraziticheskie mnogokletochnye (Vtoraya chast')] (3 vols). Leningrad: Nauka. [in Russian].

Bykhovskaya-Pavlovskaya, I. Ye. (1985) Fish Parasites [Parazity ryb]. Leningrad: Nauka. [in Russian].

Davydov, O. N. and Temnikhanov, Yu. D. (2003) Diseases of Freshwater Fish [Bolezni presnovodnykh ryb]. Kiev: Vetinform, 2003. ISBN 9667063119. [in Russian].

Davydov, O. N., Bazeev, R. E., Kurovskaya, L. Ya. and Temnikhanov, Yu. D. (2005) 'Changes in helminth number during introduction of herbivorous fish into Kiev water basin' [Izmeneniya chislennosti gel'mintov pri introduktsii rastitel'noyadnykh ryb v Kievskom vodokhranilishche], Vestnik zoologii. Supplement, 19(1), pp.96-97. Available at: http://ma
il.izan.kiev.ua/vz-pdf/suppl/Supplement\%202005-19-1.pdf. [in Russian].

Davydov, O. N., Neborachek, S. I., Kurovskaya, L. Ya. and Lysenko, V. N. (2011) Ecology of Fish Parasites in Water-Bodies of Ukraine [Ekologiya parazitov ryb vodoemov Ukrainy]. Kiev. ISBN 9789660262348. [in Russian].

Davydov, O. N., Lysenko, V. N., Kurovskaya, L. Ya. and Neborachek, S. I. (2012) 'Analysis of the species diversity of the Prussian carp parasites in the Southern Palearctic' [Analiz vidovogo raznoobraziya parazitov karasya serebryanogo Yuzhnoy Palearktiki], Fisheries Science of Ukraine [Rybohospodarska nauka Ukrainy], 3-4, pp. 63-72. Available at: http://nbuv.gov.ua/UJRN/rnu_2012_3-4_16. [in Russian].

Dunn, A. M. and Hatcher, M. J. (2015) 'Parasites and biological invasions: Parallels, interactions, and control', Trends in Parasitology, 31(5), pp. 189-199. doi: 10.1016/j.pt.2014.12. 003.

Georgieva, S., Soldánová, M., Pérez-del-Olmo, A., Dangel, D. R., Sitko, J., Sures, B. and Kostadinova, A. (2013) 'Molecular prospecting for European Diplostomum (Digenea: Diplostomidae) reveals cryptic diversity', International Journal for Parasitology, 43(1), pp. 57-72. doi: 10.1016/j.ijpara.2012.10. 019.

Hrynzhevskyi, M. V. (1998) Aquaculture of Ukraine (Organizational and Economic Aspects) [Akvakultura Ukrainy (orhanizatsiino-ekonomichni aspekty)]. Lviv: Vilna Ukraina. ISBN 96607306194. [in Ukrainian].

Jithila, P. J. and Prasadan, P. K. (2018) 'Description of Tetracotyle wayanadensis $\quad$ n. sp. (Digenea: Strigeidae) metacercaria infecting six species of freshwater fishes from Western Ghats, India, Journal of Parasitic Diseases, 42(2), pp. 226-231. doi: 10.1007/s12639-018-0988-9.

Katyukha, S. M. and Orel, A. M. (2018) 'The role of aboriginal fish in the emergence of an invasion in invading species' [Rol aboryhennykh ryb u vynyknenni invazii sered ryb- 
vselentsiv], Veterinary Biotechnology [Veterynarna biotekhnolohiia], 32(2), pp. 230-235. doi: 10.31073/vet_biotech32(2)-27. [in Ukrainian].

Katiukha, S. M. and Vozniuk, I. O. (2016) 'Spreading of parasitic diseases of fishes in the ponds of the Rivne Oblast' [Poshyrennia invaziinykh khvorob ryb u vodoimakh Rivnenskoi oblasti], Veterinary Biotechnology [Veterynarna biotekhnolohiia], 28, pp.94-101. Available at: http://nbuv.gov.ua/UJRN/vbtb_ 2016_28_12. [in Ukrainian].

Lux, E. (1990) 'Population dynamics and interrelationships of some Dactylogyrus and Gyrodactylus species on Cyprinus carpio', Angewandte Parasitologie, 31(3), pp. 143-149.

Mandyhra, M. S. and Zbozhynska, O. V. (2008) 'Epizootic situation in fish farms of Rivne Region' [Epizootychna sytuatsiia v rybnytskykh hospodarstvakh Rivnenshchyny], Veterinary Medicine [Veterynarna medytsyna], 90, pp.311-315. [in Ukrainian].

Markevich, A. P. (1951) Parasite Fauna of Freshwater Fish of the Ukrainian SSR [Parazitofauna presnovodnykh ryb Ukrainskoy SSR]. Kiev: Publishing House of the Academy of Sciences of Ukrainian. [in Russian].

Mikheev, V. N., Pasternak, A. F. and Valtonen, E. T. (2003) 'How do fish ectoparasites Argulus spp. (Crustacea: Branchiura) match with their hosts at the behavioural and ecological scales?', Journal of General Biology [Zhurnal Obshchei Biologii], 64(3), pp. 238-247.

Molnár, K. (1996) 'Remarks on the morphology, site of infection and validity of some coccidian species from fish', Acta Veterinaria Hungarica, 44(3), pp. 295-307.

Molnár, K. and Székely, C. (2014) 'Tissue preference of some myxobolids (Myxozoa: Myxosporea) from the musculature of European freshwater fishes', Diseases of Aquatic Organisms, 107(3), pp. 191-198. doi: 10.3354/dao02688.
Ondracková, M., Reichard, M., Jurajda, P. and Gelnar, M. (2004) 'Seasonal dynamics of Posthodiplostomum cuticola (Digenea, Diplostomatidae) metacercariae and parasiteenhanced growth of juvenile host fish', Parasitology Research, 93(2), pp. 131-136. doi: 10.1007/s00436-004-1123-7.

Oros, M., Hanzelová, V. and Scholz, T. (2009) 'Tapeworm Khawia sinensis: Review of the introduction and subsequent decline of a pathogen of carp, Cyprinus carpio', Veterinary Parasitology, 164(2-4), pp. 217-222. doi: 10.1016/j.vetpar.2009. 05.010.

Pukalo, P. Ya. and Loboiko, Yu. V. (2005) 'The most common diseases of pond fish and their prevention' [Naibilsh poshyreni zakhvoriuvannia stavovykh ryb ta yikh profilaktyka], Farmer [Silskyi hospodar], 11/12, pp. 36-37. [in Ukrainian].

Sachuk, R. M. and Yuskiv, I. D. (2010) 'Ecological and parasitological monitoring of carp in fish farms of Rivne Region' [Ekoloho-parazytolohichnyi monitorynh koropa v rybovodnykh hospodarstvakh Rivnenskoi oblasti], Scientific Messenger of Lviv National University of Veterinary Medicine and Biotechnologies named after S. Z. Gzhytskyj [Naukovyi visnyk Lvivskoho natsionalnoho universytetu veterynarnoi medytsyny ta biotekhnolohii imeni S. Z. Gzhytskoho], 12(2), pt. 1, pp. 274-278. Available at: http://nbuv.gov.ua/UJRN/nvlnu_2010_12_2(1)_ 57. [in Ukrainian].

Scholz, T., Kuchta, R. and Williams, C. (2012) 'Bothriocephalus acheilognathi, in Woo, P. T. K. and Buchmann, K. (eds.) Fish Parasites: Pathobiology and Protection. Wallingford: CABI, pp. 282-297. doi: 10.1079/9781845938062.0282.

Van Emden, H. F. (2019) Statistics for Terrified Biologists. $2^{\text {nd }}$ ed. Hoboken, NJ: John Wiley \& Sons. ISBN 9781119563679.

Wei, J. Z., Li, H. and Yu, H. (2013) 'Ichthyophthiriasis: emphases on the epizootiology', Letters in Applied Microbiology, 57(2), pp. 91-101. doi: 10.1111/lam.12079. 